\title{
The Use of Negative Pressure in Medicine
}

\author{
Osama Sharafeldin Abbadi
}

\section{Osama Sharafeldin Abbadi}

Department of Biochemistry, Faculty of Medicine, Omdurman Islamic University, SUDAN.

\section{*Correspondence}

\section{Osama Sharafeldin Abbadi} Department of Biochemistry, Faculty of Medicine, Omdurman Islamic University, SUDAN.

Phone: 00966531549824

Email: aslikhalis@yahoo.com

\section{History}

- Submission Date: 03-08-2020;

- Review completed: 04-09-2020;

- Accepted Date: 14-09-2020.

DOI : 10.5530/ijcep.2020.7.3.23

Article Available online http://www.ijcep.org

\section{Copyright}

(c) 2020 Phcog.Net. This is an openaccess article distributed under the terms of the Creative Commons Attribution 4.0 International license.

\begin{abstract}
Pressure is considered negative if it is below the standard atmospheric pressure, i.e. one atmosphere (1 atm). Negative pressure could occur naturally in few occasions such as out space, but it also could be deliberately inducted for the use of human. One of these uses is for medical purposes. The history of negative pressure use in health and disease management draws back to the establishment of the Chinese traditional medicine and continued to develop till the contemporary medical advances. In this review, the author aimed to elaborate the history and advancement in the usage of negative pressure in health aspects and classify the different modalities of negative pressure incorporated in treatment management and clinical trials.
\end{abstract}

Key words: Negative Pressure, Vacuum Pressure, Intermittent Negative Pressure, Wound Therapy, Delivery.

\section{INTRODUCTION}

\section{Negative Pressure}

Pressure is defined as the strain exerted on certain sizable area by a defined power. $^{[1]}$ It is usually measured by devices that depend on either fluid displacement techniques, or non-fluid techniques. ${ }^{[2]}$ Generally, Mercury is used in measurement of pressure is because of its high density (13.6 g per cubic centimeter), which allows the measurement of wide range of pressure in a shorter height of a tube. Pressure fluid equation is:

\section{$\mathbf{P}=\mathbf{p}^{\star} \mathbf{g}^{\star} \mathbf{h}$}

where (p) equals the fluid density per cubic millimeter, (g) is the gravitational acceleration and (h) is the height of the fluid in the measurement device. The measures of these fluid dependent techniques (manometric measures) are usually expressed in 'centimeter of water', or 'millimeter of mercury'. Other conventional units of pressure are Pascal; one newton per meter square, bar. ${ }^{[3]}$

The non-fluid techniques involve lot of examples. In medicine, they either use simple aneroid devices ${ }^{[4,5]}$ and electronic monitor devices (Table 1). ${ }^{[6]}$ Pressure as a force has no direction, but the forces related to it, such as gravity, could have a certain orientation. Pressure is supposed to have a positive value, but certain circumstances could give rise to a negative pressure, such as fluid in the pre-evaporation state, or when a flexible material is pulled against resistance in a vacuum space. ${ }^{[7]}$ This leads us to the concept of vacuum, which is, in a very concise definition, a pressure less than the atmospheric pressure.

A space which is empty of anything, cleared by mechanical forces, or put in a state of isolation, is also given the name vacuum. ${ }^{[8]} \mathrm{A}$ perfect vacuum is of a zero atmospheric pressure and it is hard, if ever possible, to be achieved. Vacuum pressures ranges from low to extremely high, ${ }^{[9]}$ the lowest being just less than one atmosphere (1atm) and the highest measurable vacuum could be less than $\left(10^{-15} \mathrm{~atm}\right)$. Clearly, a higher vacuum means a lower pressure and vice versa. Mechanical uses of the vacuum utensils include the simple water pump, car engine turbo pump and the light bulb.

Respiratory system is a vital system in animals. It operates in a vacuum dependent manner, which starts when contraction of the diaphragm and intercostal muscles creates pressure difference between the intra-abdominal and intra-pleural cavities, the later being reduced remarkably. The air from outside, thereby, enters the lung cavity to initiate the cycle of respiration. Although the expiration is relatively a passive process, unlike inspiration, the respiratory muscles are known as the vital pump. ${ }^{[10]}$ Closing the airway passages against inspiration will convert the lung cavity into a transient vacuum and the explanation here is very simple; the closed space which is pre-occupied with respiratory gases are now expanding without any increase in its volume, thereby the power exerted by the contained gases is now relatively lowered. Opening the air passages, nose and mouth, will restore the balance and resume the respiration.

\section{The Effects of Negative Pressure on \\ Tissues}

The effects of negative pressure in living organisms had been studied extensively in the era of space. When the mammalian body is exposed to reduced pressure below 47 millimeter of mercury $(\mathrm{mmHg})$, 
gas bubbles are formed in the circulating fluid. ${ }^{[11]}$ In the past, this condition, which was known as Ebullism, had led to fatalities, but now it seldom does because of the proper management. ${ }^{[11]}$ Ebullism was later explained by the Vacuum phenomenon; ${ }^{[12]}$ when the pressure in body cavities decreases, gases that were previously soluble in the solution will escape, causing ebullism. Skin could swell; visible small hemorrhages could appear in the eye and buccal mucosa.

The ebullism is also responsible of the decompression sickness (DCS) ${ }^{[13-15]}$ which occur to the astronauts who participate in space extravehicular activity (EVA). ${ }^{[15,16]}$ The common symptoms of DCS are joint and muscle pain, numbness and tingling and rarely skin swelling and itching. Few ebullism victims also suffered with suffocation and neurological manifestations such as memory loss, convulsions and visual disturbances. ${ }^{[13]}$

According to the Tokumaru's review (1997), DCS could be prevented by breathing pure oxygen before the EVA, developing a more efficient space suit and following the slow decompression and recompression protocol. ${ }^{[16]}$ Experiments on plants such as wheat, lettuce and radish had shown their ability to withstand a short period of decompression. ${ }^{[17]}$ After restoration to the normal pressure and gas concentration, these plants resumed growth without any apparent damage. ${ }^{[17]}$ Tardigrades have remarkable tolerance to the low pressure state. These eight legged micro-invertebrates had shown their resistance to the low pressure environment in experiments. The most accepted explanation for that is their ability to withstand severe thirst and radiation. ${ }^{[18,19]}$

In this review, negative pressure was classified into two broad categories: continuous negative pressure and intermittent negative pressure. This classification highlights the most important physical difference and simplifies the flow of information in literature.

\section{Continuous Negative Pressure}

\section{Cupping}

The use of vacuum negative pressure in medicine goes back to the era of ancient Egyptians and Chinese empires when cupping was invented more than five thousand years ago. ${ }^{[20]}$ From Egypt, the technique of cupping spread into Europe through Greece, ${ }^{[21]}$ then it was well accepted and practiced by Arabs and Muslims and finally reached the Americans. [20] Cupping is done by one of two methods: dry cupping and wet cupping. ${ }^{[20,22]}$ Both types cupping involves the placement of a suction tool into the skin of the patient, but in wet cupping, an incision or cut through the skin is performed to allow blood and fluids to drain. Dry cupping does not involve skin incision. ${ }^{[22]}$ Cupping had always been

Table 1: History of negative pressure use in medicine.

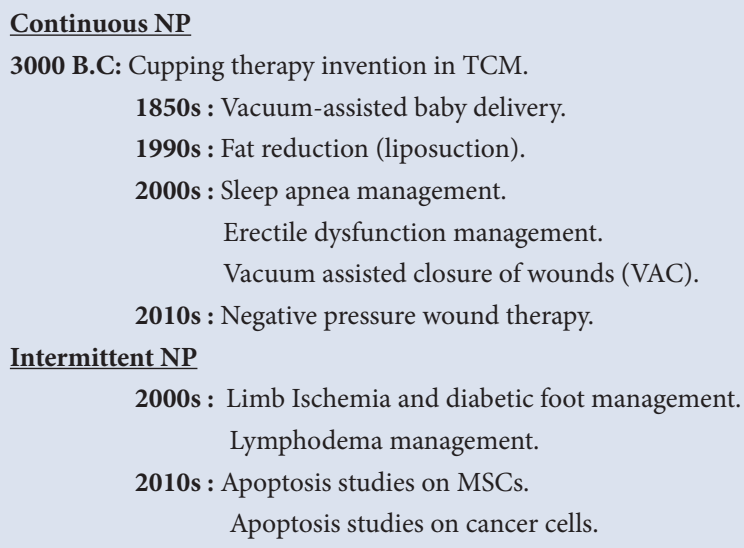

TCM: Traditional Chinese medicine; BC: Before Christ. NP: Negative pressure questionable concerning its validity and efficacy, ${ }^{[20,21,23]}$ but Cao et al. (2012) review supported the effectiveness of cupping in the treatment of acne, herpes zoster, cervical vertebra aches and facial palsy. ${ }^{[23]}$ Although cupping was used since its discovery in a very long list of diseases, ${ }^{[20]}$ its use as an adjuvant to convenient therapies is more effective, safe and acceptable. ${ }^{[22]}$ The possible mechanism by which cupping gives a result is still unclear. Some tribes believed that it clarifies souls from demons, other more reasonable theory suggest its role of relieving congestion, ${ }^{[20]}$ but removal of toxic waste and oxidative materials could be more convincing. ${ }^{[20,22]}$ In the past times, horns and hollowed bones were used for the sucking maneuver, which was operated by the healer's mouth, but nowadays more advanced kits, made from glass, plastic, or silicone, are used with manual or automated suction devices. ${ }^{[20]}$ What could be taken against cupping, beside its uncertain efficacy, is the pain and scarring of the skin, particularly with wet cupping and the possibility of infection. [20,21] Nowadays, cupping is widely promoted by alternative medicine consultants and gained a lot of acceptance in the modern world. It is a genuine part of the traditional Chinese medicine (TCM). ${ }^{[20,23]}$

\section{Negative Pressure Wound Therapy}

Negative pressure wound therapy (NPWT) modality is done by imposing a negative pressure force in a wound with the aid of an automated suction device, exudates collection chamber and a dressing kit. ${ }^{[24]}$ The aim of this process is to drain the wound site, perform an isolated dressing and hopefully give rise to the complete closure of the wound.

Healing a wound through NPWT is known as the vacuum-assisted closure of wound (VAC). ${ }^{[25]}$ The vacuum process encourages wound healing and closure presumably by increasing local hemodynamic circulation and proliferation of blood vessels, ${ }^{[24,26,27]}$ isolating the skin area from bacteria, ${ }^{[24,27]}$ and stimulating cell regeneration. ${ }^{[24,27]}$ When compared to the optimum wound dressing, NPWT proved to be superior in effect and as safe as the most advanced modality of regular wound dressing. ${ }^{[25,28]}$

NPWT is proved to be effective in the treatment of infected wounds, ${ }^{[29-31]}$ chronic wounds, ${ }^{[32,33]}$ diabetic wounds and ulcers, ${ }^{[34,35]}$ and it even accelerates the healing and prevent the complications in closed surgical wound. ${ }^{[36,37]}$ Some undesirable effects of the NPWT includes secondary infection, bleeding, pain and foreign body retention from the gauze. ${ }^{[24]}$ Despite the great results achieved by NPWT, still how it evokes healing and closure of wounds is uncertain. ${ }^{[27]}$

\section{Vacuum Erection Devices}

Vacuum Erection Devices (VED) is a device using negative pressure to obtain and restore the erectile function of the penis. ${ }^{[38,39]}$ It is composed of a chamber that contains the penis. This chamber is converted to a negative pressure ambient environment by means of a suction pump. The suction causes the corpora of the penis to distend and be filled with blood. A ring is put on the penis root to prevent the backflow of the blood. ${ }^{[39]}$ VED had been used in erectile dysfunction in relation to diabetes mellitus (EDDM) ${ }^{[38]}$ and in patients who developed erectile dysfunction after prostatectomy operation. ${ }^{[39,40]}$ The device proved high efficacy in improving the erection and restoring the penile length, particularly when used with oral Phospho-diesterase inhibitors (PDIs). $[38,39,41]$

\section{Other Uses of Continuous Negative Pressure in Medicine}

Vacuum is used for more than hundred and fifty years as an aid in the delivery of baby ${ }^{[42]}$ Its use proved to be safer for the mother, than the forceps, but it could lead to newborn injury, particularly bleeding from retina and head injuries. ${ }^{[43]}$ In another area, a study done in average weight Japanese women showed that application of negative pressure externally into the nasopharynx, succeeded to reduce the chances of sleep apnea. ${ }^{[44]}$ 
Negative pressure had been also used in nasal septum defect correction, as an alternative technique to stabilize the septum rather than the traditional packing; ${ }^{[45]}$ with the negative pressure, the pain is minimal, the discomfort is less and breathing is normal post-operatively. ${ }^{[45]}$ The process of lipid aspiration done in case of fat reduction (liposuction), or fat grafting, is also performed through negative pressure suction. ${ }^{[46,47]}$ It is performed either by machine or if the amount of fat is small, by manual syringe suction. ${ }^{[47]}$

\section{Intermittent Negative Pressure}

Intermittent Negative Pressure (INP), as the name implies, the application of negative pressure to the living tissues in intervals. It was in practice in medical and biological trials in the last two decades (Table 2). Lindstedt et al. (2008) compared the direct use of continuous negative pressure versus INP on bovine hearts and concluded that both the techniques significantly increased the local circulation into the cardiac muscle. ${ }^{[48]}$ Campisi et al. (2015) documented the beneficial role of INP

\section{Table 2: Important INP studies in human and animal tissues.}

\begin{tabular}{|c|c|c|c|}
\hline Year & Author & Study description & ResultS \\
\hline 2008 & $\begin{array}{l}\text { Lindstedt } \\
\quad \text { et al. }\end{array}$ & $\begin{array}{c}\text { On the effects of } \\
\text { continuous negative } \\
\text { pressure vs. INP on bovine } \\
\text { hearts }\end{array}$ & $\begin{array}{l}\text { both significantly } \\
\text { increased the local } \\
\text { circulation into the } \\
\text { cardiac muscle. }{ }^{[48]}\end{array}$ \\
\hline 2010 & Zhang et al. & $\begin{array}{l}\text { They applied a half } \\
\text { an hour INP of low } \\
\text { magnitude to a cell culture } \\
\text { of MSCs }\end{array}$ & $\begin{array}{c}\text { cell division was } \\
\text { inhibited, apoptosis was } \\
\text { higher than usual and } \\
\text { collagen-I was over- } \\
\text { expressed. }{ }^{[52]}\end{array}$ \\
\hline 2014 & Yang et al. & $\begin{array}{l}\text { They applied INP to cell } \\
\text { culture of MSCs }\end{array}$ & $\begin{array}{l}\text { Cells shifted toward } \\
\text { apoptosis, over- } \\
\text { expressed type I } \\
\text { collagen and alkaline } \\
\text { phosphatase and } \\
\text { activated osteoblast } \\
\text { formation. }{ }^{[53]}\end{array}$ \\
\hline 2015 & Yang et al. & $\begin{array}{l}\text { The effects of intermittent } \\
\text { negative pressure on the } \\
\text { cancer of pancreas }\end{array}$ & $\begin{array}{l}\text { great percent of the } \\
\text { cancer cells were shifted } \\
\text { to apoptosis. }{ }^{[55]}\end{array}$ \\
\hline 2015 & $\begin{array}{l}\text { Campisi } \\
\text { et al. }\end{array}$ & $\begin{array}{l}\text { The role of INP } \\
\text { in lymphodema } \\
\text { management. }{ }^{[4]}\end{array}$ & \\
\hline 2016 & Sundby et al. & $\begin{array}{l}\text { Application of INP } \\
\text { through an air tight } \\
\text { chamber to the lower } \\
\text { limbs of twenty three } \\
\text { healthy volunteers }\end{array}$ & $\begin{array}{l}\text { Increased circulatory } \\
\text { flow into the feet of } \\
\text { subjects. }{ }^{[50]}\end{array}$ \\
\hline 2016 & Sundby et al. & $\begin{array}{l}\text { INP trial in four patients } \\
\text { with chronic ulcers due to } \\
\text { limb ischemia }\end{array}$ & $\begin{array}{l}\text { Three of the four } \\
\text { patients tremendously } \\
\text { improved. }{ }^{[51]}\end{array}$ \\
\hline 2017 & Sun et al. & $\begin{array}{l}\text { The possible effect of INP } \\
\text { in accelerating the healing } \\
\text { on a post-operative } \\
\text { anterior cruciate ligament } \\
\text { in a rabbit. }\end{array}$ & $\begin{array}{l}\text { Study support that } \\
\text { INP could promote the } \\
\text { healing in the junction } \\
\text { of bone and tendon. } .^{[54]}\end{array}$ \\
\hline 2018 & Liu et al. & $\begin{array}{l}\text { The effect of low INP on } \\
\text { breast cancer cells }\end{array}$ & $\begin{array}{l}\text { INP at }-25 \mathrm{mmhg} \\
\text { apparently increased the } \\
\text { invasiveness of MDA- } \\
\text { MB-231 triple negative } \\
\text { breast cancer cells. }{ }^{[56]}\end{array}$ \\
\hline
\end{tabular}

INP: Intermittent negative pressure; MSCs: Mesenchymal stem cells. as adjunct to lymphodema management. ${ }^{[49]}$ Sundby et al. operated INP through an air tight chamber to the lower limbs of 23 healthy volunteers; the experiment resulted in increased circulatory flow into the feet of subjects. ${ }^{[50]}$ Sundby et al. conducted an INP trial in 4 patients with chronic ulcers due to limb ischemia. ${ }^{[51]}$ Within two month, three of the four patients tremendously improved and the fourth patient's ulcer was completely healed. ${ }^{[51]}$ Sundby group used INP in short intervals; ten seconds negative pressure and seven seconds of normalized pressure and the legs of the patients and volunteers in the previous experiments, were placed in a shoe shaped polymer to isolate the foot. ${ }^{[50,51]}$ Zhang et al. (2010) worked on mesenchymal stem cells (MSCs) and studied how INP could determine their offspring and velocity of division. ${ }^{[52]}$ They applied INP at low magnitude for about half an hour; unexpectedly, cell division was inhibited, apoptosis (programmed cell death) was higher than usual and collagen-I was over-expressed. ${ }^{[52]}$ Yang et al. (2014) operated a similar study on MSCs and concluded that cells shifted towards apoptosis, overexpressed type I collagen and alkaline phosphatase (ALP) and activated osteoblast formation. ${ }^{[53]}$ Sun et al. (2017) studied the possible effect of INP in accelerating the healing on a post-operative anterior cruciate ligament in a rabbit. ${ }^{[54]}$ The experiment showed accelerated osteogenesis and reduction in the inflammatory markers (TNF- $\alpha$ and IL-1 $\beta$ ) in the group that underwent INP. Study supported that INP could promote the healing in the junction of bone and tendon. ${ }^{[54]}$

\section{INP and Cancer}

From these last three studies, rising evidences were guiding scientists to test the ability of intermittent negative pressure to shift malignant cells toward apoptosis. Yang et al. studied the effects of INP on the pancreatic cancer. Cultured pancreatic cells, subjected to two levels of negative pressure showed decreased vitality and a great percent of them were shifted to apoptosis. ${ }^{[55]}$ Liu et al. worked in triple negative breast cancer cells; moderate INP at $-25 \mathrm{mmHg}$ apparently increased the malignancy extent and expression of inflammatory markers, particularly IL- 8 and TNF. ${ }^{[56]}$ INP causing expression of immune markers could be due to tissue injury, which is known to stimulate TNF and interleukin secretion, or even a generalized inflammatory reaction. ${ }^{[57]}$

\section{CONCLUSION}

Pressure is assumed to be negative if it is less than one atmosphere. This occurs naturally in the outer space, but it could be induced by vacuum pumps. Exposure of living tissues to negative pressure could lead to damage and creation of the ebullism and decompression sickness. Certain living organisms have high adaptability to negative pressure, such as Tardigrades and plants generally. The Chinese were the first to introduce negative pressure in the management of disease by the invention of cupping therapy. In the recent decades, more applications of negative pressure in health appeared, such as vacuum assisted delivery, liposuction, vacuum assisted closure of wound, sleep apnea management and erectile dysfunction management. The use of negative pressure of intermittent nature (INP) emerged in the last decade and is still under study. Its use had been mainly on trial for circulatory enhancement, particularly for diabetic patients. Since 2010, INP was used in the apoptosis studies on mesenchymal stem cells (MSCs) and cancer cells and the results showed discrepancy.

\section{ACKNOWLEDGEMENT}

The author would like to thank the King Abdullah Specialized children's hospital library administrators in Riyadh, Saudi Arabia for their help and support in this review. 


\section{ABBREVIATIONS}

ALP: Enzyme alkaline phosphatase; ATM: Atmosphere; DCS Decompression Sickness; EDDM: Erectile Dysfunction in Relation to Diabetes Mellitus; EVA: Extravehicular Activity; IL-1 $\beta$ : Interlukin 1 Beta; INP: Intermittent Negative Pressure; MSCs: Mesenchymal Stem Cells; NPWT: Negative Pressure Wound Therapy; PDIs: Phosphodiesterase Inhibitors; TCM: Traditional Chinese Medicine; TNF- $\alpha$ : Tumor Necrosis Factor alpha; VAC: Vacuum Assisted Closure of Wounds; VED: Vacuum Erection Device.

\section{REFERENCES}

1. Jacob DJ. Introduction to Atmospheric Chemistry. $1^{\text {st }}$ Ed. Princeton (NJ): Princeton University Press. 1999.

2. Harrison RG. Meteorological Measurements and Instrumentation. $1^{\text {st }}$ Ed. New York (NY): John Wiley and Sons, Ltd. 2015

3. Cuscó L. Guide to Measurement of pressure and Vacuum. $1^{\text {st }}$ Ed. London, UK: The institute of Measurement and Control. 1998

4. Krass ME, LaBarber LP, Torres MA. Blood pressure measurement in family physician offices. Fam Med. 1988;20(1):25-7.

5. Mattoo TK. Arm cuff in the measurement of blood pressure. Am J Hypertens. 2002;15(S2):67S-8S

6. Kallem RR, Meyers KE, Cucchiara AJ, Sawinski DL, Townsend RR. Blood pressure variability of two ambulatory blood pressure monitors. Blood Press Monit. 2014;19(2):98-102.

7. Wright K. The Physics of Negative Pressure: The universe doesn't just blow, sometimes it sucks. Discover. 2003

8. The Merriam-Webster dictionary. Definition of vacuum. URL: https://www. merriam-webster.com/dictionary/vacuum.

9. Wilson TA, DeTroyer A. Diagrammatic analysis of the respiratory action of the diaphragm. J Appl Physiol. 2010;108(2):251-5.

10. Decramer M. Action and interaction of respiratory muscles in dogs. Verh K Acad Geneeskd Belg. 1990;52(2):141-201.

11. Murray DH, Pilmanis AA, Blue RS, Pattarini JM, Law J, Bayne CG, et al. Pathophysiology, prevention and treatment of ebullism. Aviat Space Environ Med. 2013;84(2):89-96.

12. Yanagawa Y, Ohsaka H, Jitsuiki $K$, Yoshizawa T, Takeuchi I, Omori K, et al. Vacuum phenomenon. Emerg Radiol. 2016;23(4):377-82.

13. Ryles MT, Pilmanis AA. The initial signs and symptoms of altitude decompression sickness. Aviat Space Environ Med. 1996;67(10):983-91.

14. Hundemer GL, Jersey SL, Stuart RP, Butler WP, Pilmanis AA. Altitude decompression sickness incidence among U-2 pilots: 1994-2010. Aviat Space Environ Med. 2012;83(10):968-74.

15. Katuntsev VP, Osipov YY, Barer AS, Gnoevaya NK, Tarasenkov GG. The main results of EVA medical support on the Mir Space Station. Acta Astronaut. 2004;54(8):577-83.

16. Tokumaru O. Prevention of decompression sickness during extravehicular activity in space: A review. Boei Ika Daigakko Zasshi. 1997;22(4):223-32.

17. Wheeler RM, Wehkamp CA, Stasiak MA, Dixon MA, Rygalov VY. Plants survive rapid decompression: Implications for bioregenerative life support. Adv Space Res. 2011;47(9):1600-7.

18. Jönsson KI, Rabbow E, Schill RO, Harms-Ringdahl M, Rettberg P. Tardigrades survive exposure to space in low Earth orbit. Curr Biol. 2008;18(17):R729-31.

19. Jönsson KI. Tardigrades as a potential model organism in space research. Astrobiology. 2007;7(5):757-66.

20. Qureshi NA, Ali GI, Abushanab TS, El-Olemy AT, Alqaed MS, El-Subai IS, et al. History of cupping (Hijama): A narrative review of literature. J Integr Med. 2017; 15(3):172-81

21. Zaidi SMA, Jameel SS, Jafri K, Khan SA, Ahmad E. Ilaj bil hijamah (cupping therapy) in the Unani system of medicine: anecdotal practice to evidence based therapy. Acta Med Hist Adriat. 2016;14(1):81-94.

22. Vakilinia SR, Bayat D, Asghari M. Hijama (Wet Cupping or Dry Cupping) for Diabetes Treatment. Iran J Med Sci. 2016;41(3):S37.

23. Cao H, Li X, Liu J. An updated review of the efficacy of cupping therapy. PLoS One. 2012;7(2):e31793.

24. Rhee SM, Valle MF, Wilson LM, Lazarus G, Zenilman JM, Robinson KA. Negative Pressure Wound Therapy Technologies for Chronic Wound Care in the Home Setting. Agency for Healthcare Research and Quality (US): Technology Assessment Report. 2014. URL: https://www.ncbi.nlm.nih.gov/pubmedhealth/ $\mathrm{PM} \mathrm{H0073349/}$

25. Blume PA, Walters J, Payne W, Ayala J, Lantis J. Comparison of negative pressure wound therapy using vacuum-assisted closure with advanced moist wound therapy in the treatment of diabetic foot ulcers: A multicenter randomized controlled trial. Diab Care. 2008;31(4):631-6.
26. Erba $P$, Ogawa R, Ackermann M, Adini A, Miele LF, Dastouri $P$, et al Angiogenesis in wounds treated by microdeformational wound therapy. Ann Surg. 2011;253(2):402-10

27. Schintler MV. Negative pressure therapy: theory and practice. Diabetes Metab Res Rev. 2012;28(1):72-9.

28. Sajid MT, Mustafa Qu, Shaheen N, Hussain SM, Shukr I, Ahmed M. Comparison of negative pressure wound therapy using vacuum-assisted closure with advanced moist wound therapy in the treatment of diabetic foot ulcers. J Coll Physicians Surg Pak. 2015;25(11):789-93.

29. Zhou M, Yu A, Wu G, Xia C, Hu X, Qi B. Role of different negative pressure values in the process of infected wounds treated by vacuum-assisted closure: An experimental study. Int Wound J. 2013;10(5):508-15.

30. Monsen C, Wann-Hansson C, Wictorsson C, Acosta S. Vacuum-assisted wound closure versus alginate for the treatment of deep perivascular wound infections in the groin after vascular surgery. J Vasc Surg. 2014;59(1):145-51.

31. Walma MS, Burbach JP, Verheijen PM, Pronk A, Grevenstein WMV. Vacuumassisted closure therapy for infected perineal wounds after abdominoperineal resection: A retrospective cohort study. Int J Surg. 2016;26:18-24.

32. Schwartz JA, Goss SG, Facchin F, Gendics C, Lantis JC. Single-use negative pressure wound therapy for the treatment of chronic lower leg wounds. Wound Care. 2015;24(2):4-9.

33. Ross RE, Aflaki P, Gendics C, Lantis li JC. Complex lower extremity wounds treated with skin grafts and NPWT: A retrospective review. J Wound Care. $2011 ; 20(10): 490-5$

34. Dumville JC, Hinchliffe RJ, Cullum N, Game F, Stubbs N, Sweeting M, et al. Negative pressure wound therapy for treating foot wounds in people with diabetes mellitus. Cochrane Database Syst Rev. 2013;10:CD010318.

35. Yarwood-Ross L, Dignon AM. NPWT and moist wound dressings in the treatment of the diabetic foot. Br J Nurs. 2012;21(15):S26-32.

36. Stannard JP, Gabriel A, Lehner B. Use of negative pressure wound therapy over clean, closed surgical incisions. Int Wound J. 2012;9(1):32-9.

37. Itani HE. Reviewing the benefits and harm of NPWT in the management of closed surgical incisions. Br J Community Nurs. 2015;20(6):S28-34.

38. Sun L, Peng FL, Yu ZL, Liu CL, Chen J. Combined sildenafil with vacuum erection device therapy in the management of diabetic men with erectile dysfunction after failure of first-line sildenafil monotherapy. Int J Urol. 2014;21(12):1263-7.

39. Lin $H$, Wang G, Wang R. Application of the vacuum erectile device in penile rehabilitation for erectile dysfunction after radical prostatectomy. Zhonghua Nan Ke Xue. 2015;21(3):195-9.

40. Zippe CD, Pahlajani G. Vacuum erection devices to treat erectile dysfunction and early penile rehabilitation following radical prostatectomy. Curr Urol Rep. 2008;9(6):506-13

41. Chen J, Sofer M, Kaver I, Matzkin H, Greenstein A. Concomitant use of sildenafil and a vacuum entrapment device for the treatment of erectile dysfunction. J Urol. 2004;171(1):292-5.

42. Suwannachat $B$, Lumbiganon $P$, Laopaiboon $M$. Rapid versus stepwise negative pressure application for vacuum extraction assisted vaginal delivery. Cochrane Database Syst Rev. 2008;3:CD006636.

43. Johanson RB, Menon BK. Vacuum extraction versus forceps for assisted vaginal delivery. Cochrane Database Syst Rev. 2000;2:CD000224.

44. Kato S, Isono S, Amemiya M, Sato S, Ikeda A, Okazaki J, et al. Submenta negative pressure application decreases collapsibility of the passive pharyngeal airway in non-obese women. J Appl Physiol. 2015;118(7):912-20.

45. Skoulakis CE, Papadakis CE, Manios AG, Prokopakis EP, Nikolidakis AA Velegrakis $\mathrm{GA}$, et al. Negative pressure suction in nasal septum surgery. Rhinology. 1999;37(2):86-7.

46. Rodriguez RL, Condé-Green A. Quantification of negative pressures generated by syringes of different calibers used for liposuction. Plast Reconstr Surg 2012;130(2):383-4.

47. Kahveci R, Rehimli M, Esmer A, Rehimli S, Kanturk R, Menderes V. A useful technique to obtain adequate negative pressure for liposuction. J Plast Reconst Aesthet Surg. 2009;62(12):e604-5.

48. Lindstedt S, Malmsjö M, Gesslein B, Ingemansson R. Evaluation of continuous and intermittent myocardial topical negative pressure. J Cardiovasc Med. 2008;9(8):813-9.

49. Campisi CC, Ryn M, Campisi CS, DiSumma P, Boccardo F, Campisi C. Intermittent Negative pressure therapy in the combined treatment of peripheral Lymphoedema. Lymphology. 2015;48(4):197-204.

50. Sundby $\varnothing \mathrm{H}$, Høiseth LØ, Mathiesen I, Jørgensen JJ, Weedon-Fekjær H, Hisdal $\mathrm{J}$. Application of intermittent negative pressure on the lower extremity and its effect on macro- and microcirculation in the foot of healthy volunteers. Physiol Rep. 2016;4(17):e12911.

51. Sundby $\varnothing \mathrm{H}$, Høiseth LØ, Mathiesen I, Jørgensen JJ, Sundhagen JO, Hisdal J The effects of intermittent negative pressure on the lower extremities' peripheral circulation and wound healing in four patients with lower limb ischemia and hard-to-heal leg ulcers: A case report. Physiol Rep. 2016;4(20):e12998.

52. Zhang YG, Yang Z, Zhang $H$, Wang $C$, Liu M, Guo X et al. Effect of negative pressure on human bone marrow mesenchymal stem cells in vitro. Connect 
Tissue Res. 2010;51(1):14-21.

53. Yang Z, Yao JF, Xu P, Zhang JB, Zhang YM, Zhu YJ, et al. Functions and mechanisms of intermittent negative pressure for osteogenesis in human bone marrow mesenchymal stem cells. Mol Med Rep. 2014;9(4):1331-6.

54. Sun Z, Wang X, Ling M, Wang W, Chang Y, Yang G, et al. Acceleration of tendonbone healing of anterior cruciate ligament graft using intermittent negative pressure in rabbits. J Orthop Surg Res. 2017;12(1):60.
55. Yang $X$, Sun B, Zhu H, Jiang Z. Suppression effects of negative pressure on the proliferation and metastasis in human pancreatic cancer cells. J Can Res Ther 2015;11(1):195-8

56. Liu W, Fu X, Yang Z, Li S, Cao Y, Li Q, et al. Moderate intermittent negative pressure increases invasiveness of MDA-MB-231 triple negative breast cancer cells. Breast. 2018;38:14-21.

57. Pugin J. How tissue injury alarms the immune system and causes a systemic inflammatory response syndrome. Ann Intens Care. 2012:2(1):27.

Cite this article: Abbadi OS. The Use of Negative Pressure in Medicine Int J Clin Exp Physiol. 2020;7(3):91-5. 